\title{
FAKTOR-FAKTOR YANG MEMENGARUHI HYGIENE GENITALIA PADA REMAJA PUTRI SAAT MENSTRUASI DI PONDOK PESANTREN DAIRI SIDIKALANG TAHUN 2021
}

\author{
Lusiana Berampu $^{1}$, Sarma Lumbanraja ${ }^{2}$, Asriwati $^{3}$ \\ ${ }^{1,2,3}$ Institut Kesehatan Helvetia Medan, Medan \\ Email: lusianaberampu21@gmail.com
}

\begin{abstract}
Abstrak
WHO melaporkan bahwa kanker serviks adalah kanker yang paling umum keempat dikalangan wanita dengan kasus tahun 2018 sebesar 570.000. Strategi global untuk menghilangkan kanker serviks oleh WHA dengan merekomendasikan pendekatan komprehensif melalui strategi preventif primer pada anak laki-laki dan perempuan mencakup pendidikan seks disesuaikan dengan usai dan budaya. Tujuan penelitian untuk menganalisis pengaruh pengetahuan, sikap, sumber informasi, dukungan guru/ustadzah, dukungan keluarga dan faktor yang paling berpengaruh terhadap Hygiene Genitalia pada remaja putri saat menstruasi di Pondok Pesantren Dairi Sidikalang Tahun 2021.

Metode penelitian menggunakan survey analitik dengan pendekatan cross sectional. Populasi sebanyak 101 remaja putri dengan teknik pengambilan sampel menggunakan total populasi. Data dikumpulkan menggunakan kuesioner dan analisa data adalah univariat, bivariat dan multivariat.

Hasil penelitian menggunakan uji regresi linier berganda menunjukkan nilai sig pengatahuan $0,008 \mathrm{OR}=22,920 \mathrm{CI} 2,231-235,477$, sikap $0,005 \mathrm{OR}=4,471 \mathrm{CI}$ 1,573-12,707, sumber informasi 0,008 OR=4,428 CI 1,474-13,306, dukungan guru/ustadzah 0,013 OR=3,645 CI 1,31610.099, dan dukungan keluarga 0,971 OR=0,981 CI 0,336-2,858.

Kesimpulan ada pengaruh pengetahuan, sikap sumber infromasi, dukungan guru/ustadzah dan tidak ada pengaruh dukungan keluarga terhadap hygiene genitalia pada remaja putri saat menstruasi. Variabel paling berpengaruh adalah pengetahuan. Diharapkan kepada dinas pendidikan/Depag membuat sebuah kebijakan tentang kurikulum kesehatan reproduksi kepada remaja untuk mendukung pengetahuan, sikap dan tindakan anak remaja berkaitan dengan kesehatan terutama reproduksinya dan berkomitmen dengan dinas kesehatan untuk menyediakan tenaga kesehatan dan tenaga pendidik basic kespro untuk berkordinasi dalam memberikan KIE kepada remaja.
\end{abstract}

Kata Kunci : Hygiene Genitalia, Remaja Putri, Menstruasi

\section{Abstract}

WHO in its survey in several countries explained that young women aged 10-14 years have problems with their reproduction. The highest incidence of reproductive tract infections (ISR) in the world is in adolescents (35\%-42\%) and young adults (27\%-33\%), candidiasis prevalence (25-50\%), bacterial vaginosis (20-40\%)) and trichomoniasis (5-15\%). The purpose of the study was to analyze the influence of knowledge, attitudes, sources of information, teacher/ustadzah support, family support and the most influential factors on Genital Hygiene in adolescent girls during menstruation at the Dairi Sidikalang Islamic Boarding School in 2021.

The research method uses an analytical survey with a cross sectional approach. The population is 101 young women with a sampling technique using the total population. Data were collected using questionnaires and data analysis was univariate, bivariate and multivariate.

The results of the study using multiple linear regression test showed that the knowledge sig value was 0.008 OR=22,920 CI 2,231-235,477, attitude was 0,005 OR=4,471 CI 1,573-12,707, 
source of information was 0,008 OR=4,428 CI 1,474-13,306, teacher support was 0,013 $O R=3,645$ CI 1.316-10,099, and family support 0,971 OR=0,981 CI 0,336-2,858.

The conclusion is that there is an influence of knowledge, attitude of sources of information, support of teachers/ustadzah and no influence of family support on genital hygiene in adolescent girls during menstruation. The most influential variable is knowledge. It is hoped that the education office / Ministry of Religion will make a policy on reproductive health curriculum for adolescents to support the knowledge, attitudes and actions of adolescents related to health, especially reproductive health and commit to the health office to provide health workers and basic health education educators to coordinate in providing IEC to adolescents. .

Keywords: Genital Hygiene, Young Women, Menstruation

\section{Pendahuluan}

Berdasarkan konferensi Internasional kependudukan dan pembangunan dicetuskan bahwa kesehatan reproduksi adalah keadaan sehat yang menyeluruh, meliputi aspek fisik, mental dan sosial, dan bukan sekedar tidak adanya penyakit atau gangguan di segala hal yang berkaitan dengan sistem reproduksi, fungsinya maupun proses reproduksi itu sendiri (Noviana, 2016). Ruang lingkup reproduksi mencakup keseluruhan kehidupan manusia sejak lahir hingga meninggal. Pendekatan yang diterapkan dalam menguraikan ruang lingkup kesehatan reproduksi adalah pendekatan siklus hidup, yang artinya memperhatikan kekhususan kebutuhan penanganan sistem reproduksi pada setiap fase kehidupan, serta kesinambungan antar fase kehidupan tersebut. Dengan demikian masalah kesehatan reproduksi pada setiap fase kehidupan dapat diperkirakan, yang bila tidak ditangani dengan baik maka hal ini dapat berakibat buruk pada masa kehidupan selanjutnya. Pendekatan siklus kehidupan dikenal dengan lima tahap yaitu konseps, bayi dan anak, remaja, usia subur, usia lanjut (Irianto, 2015).

World Health Organization (WHO) tahun 2019 melaporkan bahwa jumlah remaja di dunia sebanyak 1,2 milyar dengan total 1/6 dari jumlah populasi secara global. Jumlah ini diperkirakan akan terus meningkat hingga tahun 2050, terutama di negaranegara berpenghasilan rendah dan menengah dengan di dominasi umur 10-19 tahun sebanyak 90\%. Data dari Sensus Penduduk tahun 2020 di dapatkan bahwa jumlah remaja laki-laki sebanyak 24.138.346 jiwa dan remaja perempuan sebanyak 22.734.596 jiwa dengan karekteristik umur yaitu 10-19 tahun sebanyak 223,330,975 orang dengan gambaran persentase kelompok umur 0-9 tahun sebanyak 14,36\%, 10-19 tahun sebanyak $17,34 \%, 20-29$ tahun sebanyak 16,47\%, 30-39 tahun sebanyak 16,01\%, 40-49 tahun sebanyak 14,52\%, 50-59 tahun sebanyak 10,81\%, 60-69 tahun sebanyak 6,31\%, 70-75 tahun sebanyak $3,39 \%$, Tidak diketahui sebanyak $0,75 \%$.

Menstruasi merupakan suatu kondisi fisologis yang menandakan bahwa telah terjadi sebuah proses perkembangan pada tubuhnya terutama pada organ reproduksi sendiri (Gustina \& Djannah, 2015). Pada saat menstruasi, kondisi pembuluh darah di rahim mudah terkena infeksi, sehingga memerlukan upaya untuk menjaga kebersihan vagina, dikarenakan kuman mudah sekalai masuk dan dapat menimbulkan berbagai penyakit pada saluran reproduksi.

Tujuan dari Suistainable Development Goals (SDGs) pada goals 3 dengan 9 target yaitu pada tahun 2030 mengurangi sepertiga dari kematian dini yang disebabkan oleh penyakit tidak menular, melalui tindakan pencegahan dan pengobatan serta menaikkan kesehatan mental dan kesejahteraan. Penyakit tidak menular (PTM) dewasa ini mengalami masa transisi epidemiologi yang signifikan sehingga menjadi beban utama di Indonesia. Permasalahan yang timbul berkaitan dengan organ reproduksi di masa remaja yang tidak benar dapat menyumbang tidak tercapainya goals 3 adalah yaitu menurunkan angka kejadian kanker serviks. 


\section{MIRACLE JOURNAL}

WHO melaporkan bahwa kanker serviks adalah kanker yang paling umum keempat dikalangan wanita. Secara global angka kejadian kanker serviks tahun 2018 sebesar 570.000 kasus dengan penyebab 7,5\% kematian dari seluruh penyakit kanker. Angka kematian sebanyak 311.000 kasus setiap tahun dengan $85 \%$ terjadi di negara berpenghasilan rendah dan menengah.

Data kanker serviks di Indonesia tahun 2018 sebanyak 32.469 kasus (17,2\%) dengan angka kematian sebanyak 18.279 kasus $(8,8 \%)$ dan berada pada urutan kedua setelah kanker payudara. Sementara data dari Rumah Sakit Kanker Darmais Tahun 2018 melaporkan bahwa angka kejadian kanker serviks pada wanita berada pada urutan kedua sebanyak 10,69\% setelah kanker payudara (Pangribowo, 2019). Pada tahun 2019 Kementerian Kesehatan melaporkan di Indoneisa sebanyak 5.015 kasus yang dicurigai kanker serviks dan kenaikan kasus meningkat daripada kanker payudara sebanyak 2.910 kasus. Hal ini menggambarkan bahwa kejadian kanker serviks perlu menjadi perhatian utama agar dapat ditemukan solusi pemecahannya (Pangribowo, 2019).

Padahal di dalam sekolah sendiri telah didirikan sebuah Usaha Kesehatan Sekolah (UKS) yang merupakan suatu wahana belajar mengajar untuk meningkatkan kemampuan hidup sehat, sehingga meningkatkan pertumbuhan dan perkembangan peserta didik yang harmonis dan optimal agar menjadi sumber daya manusia yang berkualitas. Ruang lingkup UKS tercermin dalam tri program usaha kesehatan sekolah (Trias UKS) berisikan penyelenggaraan pendidikan kesehatan, penyelenggaraan pelayanan kesehatan dan pembinaan lingkungan kehidupan sekolah sehat. Sesuai dengan Trias UKS pada poin penyelenggaraan pendidikan kesehatan, UKS dapat dijadikan menjadi sarana media informasi dalam memberikan pemahaman mengenai kesehatan reproduksi, terutama masalah menstruasi.

Berdasarkan hasil penelitian Yasnani dan Erawan, (2016) tentang hubungan pengetahuan, sikap, dan tindakan dengan personal hygiene menstruasi pada remaja putri di SMP Negeri Satap Bukit Asri Kabupaten Buton tahun 2016, didapatkan hasil penelitian menunjukkan ada hubungan yang signifikan antara pengetahuan ( $p$-value $=0,030)$, sikap ( $p$-value $=0,009)$, dan tindakan $(p$-value $=0,003)$ siswi dengan personal hygiene selama menstruasi. Pengetahuan diperlukan untuk menghasilkan suatu perilaku tertentu ketika menghadapi suatu keadaan tertentu seperti menstruasi, sehingga pengetahuan atau kognitif merupakan domain yang sangat penting bagi terbentuknya perilaku dan perilaku yang didasari pengetahuan akan bertahan lebih langgeng daripada perilaku yang tidak didasari oleh pengetahuan (Novianti, dkk. 2017).

Data jumlah santriwati di Pondok Pesantren Dairi Sidikalang di dapatkan kelas VIII dan IX sebanyak 130 orang dengan gambaran sudah mengalami menstruasi dari kelas VIII sebanyak 46 orang dan kelas IX sebanyak 55 orang. Dari hasil wawancara yang dilakukan kepada 10 santriwati menyatakan bahwa kurang mengetahui bagaimana pengelolaan praktik hygiene saat menstruasi, tidak pernah mendapatkan materi seputar organ reproduksi baik dari guru, ibu asrama bahkan dari tenaga medis. Wawancara dilanjutkan kepada pengajar bahwa ketidaktahuan remaja akan praktik hygiene disebabkan karena adanya rasa malu dari remaja untuk berkonsultasi pada gurunya, tidak adanya pengajar yang kompeten di bidang kesehatan reproduksi, kurang berperannya UKS sebagai wadah untuk membantu remaja mengelola kesehatannya, dan kurangnya sarana fasilitas yang mendukung informasi kesehatan reproduksi di UKS.

Kajian permasalahan yang telah dipaparkan oleh peneliti memperlihatkan bahwa pada dasarnya, masalah kesehatan reproduksi merupakan masalah yang tabu untuk dibicarakan baik dilingkungan keluarga, pendidikan dan lingkungan masyarakat akibat norma sosial, agama dan budaya yang berkembang di masyarakat terlebih lagi masyarakat pedesaan. Berdasarkan latar belakang tersebut, peneliti tertarik mengangkat 


\section{MIRACLE JOURNAL}

judul "Faktor-Faktor Yang Memengaruhi Hygiene Genitalia Pada Remaja Putri Saat Menstruasi Di Pondok Pesantren Dairi Sidikalang Tahun 2021"

\section{Metode Penelitian}

Penelitian ini termasuk dalam penelitian survey analitik dengan pendekatan cross sectional artinya tehadap subjek yang diteliti hanya diamati subjek yang terdapat pada variabel independen dengan variabel dependen yang dilakukan pengukuran dalam waktu bersamaan. Peneliti menggunakan penelitian survey analitik karena peneliti ingin menggali bagaimana dan mengapa fenomena itu terjadi, kemudian melakukan analisis dinamika korelasi antara fenomena atau antara faktor risiko dengan faktor efek. Penelitian ini menggunakan pendekatan cross sectional yang bertujuan setelah ditemukan dinamika korelasi antara faktor risiko dengan efek, maka pengumpulan data dilakukan sekaligus pada suatu saat (point time approach) (Novianti, dkk. 2017).

\section{Populasi dan sampel}

\section{Populasi}

Populasi didefinisikan sebagai kelompok subjek yang hendak dikenai generalisasi hasil penelitian. Sebagai suatu populasi, kelompok subjek ini harus memiliki ciri-ciri atau karekteristik-karakteristik bersama yang membedakannya dari kelompok subjek lain. Ciri yang dimaksud tidak terbatas hanyak sebagai ciri lokasi akan tetapi terdapat terdiri dari karakteristik-karakteristik individu (Notoatmodjo, 2012). Populasi dalam penelitian ini adalah seluruh remaja putri yang sudah mengalami menstruasi kelas VIII dan IX sebanyak 101 orang

\section{Sampel}

Sampel adalah bagian (subset) dari populasi yang terpilih dengan cara tertentu sehingga dapat mewakili populasi (Sudigdo, 2011). Dengan demikian, peneliti mempertimbangkan kondisi dan waktu, sehingga menetapkan teknik pengambilan dengan menggunakan total populasi yaitu remaja putri kelas VIII dan IX sebanyak 101 orang.

\section{Variabel dan Definisi Operasional}

\section{Variabel Penelitian}

Variabel terdiri dari variabel dependen (pengetahuan, sikap, sumber informasi, dukungan guru/ustadzah dan dukungan keluarga) dan variabel dependen (Hygiene Genitalia saat menstruasi ).

Tabel 1. Aspek Pengukuran Variabel Independen dan Variabel Dependen

\begin{tabular}{|c|c|c|c|c|c|c|}
\hline No & $\begin{array}{c}\text { Nama } \\
\text { Variabel X }\end{array}$ & $\begin{array}{c}\text { Jumlah } \\
\text { Pertanyaan }\end{array}$ & Alat ukur & Skala Pengukuran & Value & $\begin{array}{l}\text { Jenis } \\
\text { Skala } \\
\text { Ukur }\end{array}$ \\
\hline 1 & Pengetahuan & 10 & Kuesioner & $\begin{array}{l}\text { a. Baik:8-10 } \\
\text { b. Cukup:6-7 } \\
\text { c. Kurang:0-5 }\end{array}$ & $\begin{array}{l}\text { Benar=1 } \\
\text { Salah=0 }\end{array}$ & Ordinal \\
\hline 2 & Sikap & 10 & Kuesioner & $\begin{array}{l}\text { a. Baik: }>20 \\
\text { b. Kurang baik: } \leq 20\end{array}$ & $\begin{array}{l}\text { Setuju=3 } \\
\text { Ragu-Ragu=2 } \\
\text { Tidak Setuju=1 }\end{array}$ & Ordinal \\
\hline 3 & $\begin{array}{l}\text { Sumber } \\
\text { informasi }\end{array}$ & 5 & Kuesioner & $\begin{array}{l}\text { a. Baik:>3 } \\
\text { b. Kurang baik: } \leq 3\end{array}$ & $\begin{array}{l}\mathrm{Ya}=1 \\
\text { Tidak=0 }\end{array}$ & Ordinal \\
\hline
\end{tabular}




\begin{tabular}{|c|c|c|c|c|c|c|c|}
\hline 4 & $\begin{array}{l}\text { Dukungan } \\
\text { guru/ustadzah }\end{array}$ & 6 & Kuesioner & $\begin{array}{l}\text { a. } \\
\text { b. }\end{array}$ & $\begin{array}{l}\text { Mendukung:>12 } \\
\text { Kurang } \\
\text { mendukung: } \leq 12\end{array}$ & $\begin{array}{l}\text { Sering }=3 \\
\text { Kadang- } \\
\text { Kadang=2 } \\
\text { Tidak Pernah=1 }\end{array}$ & Ordinal \\
\hline 5 & $\begin{array}{l}\text { Dukungan } \\
\text { keluarga }\end{array}$ & 14 & Kuesioner & $\begin{array}{l}\text { a. } \\
\text { b. }\end{array}$ & $\begin{array}{l}\text { Mendukung:>28 } \\
\text { Kurang } \\
\text { mendukung: }<28\end{array}$ & $\begin{array}{l}\text { Sering }=3 \\
\text { Kadang- } \\
\text { Kadang=2 } \\
\text { Tidak Pernah=1 }\end{array}$ & Ordinal \\
\hline 6 & $\begin{array}{l}\text { Variabel Y } \\
\text { Higiene } \\
\text { Genitalia saat } \\
\text { menstruasi } \\
\end{array}$ & 5 & Kuesioner & & $\begin{array}{l}\text { Sesuai:>3 } \\
\text { Kurang } \\
\text { sesuai: } \leq 3\end{array}$ & $\begin{array}{l}\text { Ya }=1 \\
\text { Tidak }=0\end{array}$ & Ordinal \\
\hline
\end{tabular}

\section{Metode Pengumpulan Data}

a. Data primer di kumpulkan melalui pengisian lembar kuesioner oleh responden dan diisi langsung atau di jawab oleh responden yang bersangkutan dan dibantu oleh guru dan peneliti.

b. Data sekunder dalam penelitian ini adalah data yang telah dikumpulkan atau di dokumentasikan oleh pihak Pondok Pesantren Dairi Sidikalang berupa laporan bulanan dan tahunan.

c. Data Tersier yaitu data yang diperoleh dari berbagai referensi yang valid seperti jurnal dan data WHO,Indonesia, Provinsi dan Kota.

\section{Pengolahan dan Analisis Data \\ Pengolahan Data}

Penelitian ini dalam pengolahan data menggunakan komputer dengan aplikasi pengolahan data Ms.excel dan SPSS. Semua kuesioner yang telah diisi oleh responden diolah dengan cara komputerisasi dengan langkah - langkah sebagai berikut :

\section{Collecting}

Yaitu mengumpulkan data yang berasal dari kuesioner maupun observasi

\section{Checking}

Dilakukan dengan memeriksa kelengkapan jawaban kuesioner atau lembar obeservasi dengan tujuan agar data diolah secara benar sehingga pengolahan data memberikan hasil yang valid, reliable dan terhindar dari bias.

3. Coding

Pada langkah ini peneliti melakukan pemberian kode pada variabel-variabel yang diteliti.

\section{Entering}

Data entry, yakni jawaban-jawaban dari masing-masing responden yang masih dalam bentuk kode dimasukkan kedalam aplikasi SPSS 20.

\section{Data processing}

Semua data yang telah diinput kedalam aplikasi computer akan diolah sesuai dengan kebutuhan dari penelitian ( Notoatmodjo, 2012).

\section{Analisis data}

\section{Analisis Univariat}

Analisis univariat yang menggambarkan secara tunggal variabel-variabel penelitian baik independen maupun dependen dalam bentuk distribusi frekuensi.

2. Analisis Bivariat

Analisa bivariat merupakan analisis untuk mengetahui interaksi dua variabel, baik berupa komperatif, asosiatif maupun korelatif (Swarjana, 2015). Pada penelitian ini yang 


\section{MIRACLE JOURNAL}

dilakukan adalah tabulasi silang antara dua variabel yaitu variabel independen dan variabel dependen. Uji statistic yang digunakan adalah Chi-Square karena merupakan salah satu uji komparatif dan parametris yang tidak mensyaratkan data terdistribusi normal. Dalam penelitian ini, derajat kemaknaan (signifinance level) yang digunakan adalah $5 \%(0,05)$. Tingkat signifikansi dilambangkan dengan $\alpha$. Bila $\mathrm{p}<0,05$, maka H0 diterima yang berarti ada pengaruh antara salah satu faktor-faktor variabel terhadap Hygiene Genitalia saat menstruasi. Sebaliknya jika didapat p > 0,05, maka H0 ditolak yang berarti tidak ada pengaruh antara salah satu atau beberapa faktorfaktor variabel x terhadap Hygiene Genitalia saat menstruasi.

3. Analisis Multivariat

Uji statistic multivariat digunakan untuk menguji hubungan simultan lebih dari dua variabel. Statistik multivariat juga dapat dibedakan menjadi uji parametrik dan non parametrik. Dalam analisis multivariat, analisis dapat dibedakan menjadi analisis dependensi dan interdependensi. Dependensi berarti terdapat variabel bebas dan tidak bebas, sedangkan dalam interdependensi tidak terdapat perbedaan variabel. Untuk menguji data secara multivariat, peneliti menggunakan uji regresi linier berganda binary (logistic regression).

Regresi logistic memiliki tingkat kemiripan dengan analisis diskriminan, di gunakan peneliti untuk melakukan uji apakah probabilitas terjadinya variabel terikat (Y) dapat diprediksi oleh variabel-variabel bebasnya (X1...X2...Xn). Untuk melakukan analisis data dapat dijabarkan sebagai berikut:

1. Melakukan analisis bivariat

Apabila variabel bebas adalah varaiabel kategorikal, analisis bivariat yang digunakan adalah chi-square dan apabila variabel bebas adalah variabel numerik, analisis bivariat yang digunakan adalah uji t tidak berpasangan atau mann-whitney.

2. Menyeleksi variabel yang akan dimasukkan ke dalam analisis regresi logistik

Variabel yang dimasukkan ke dalam analisis regresi logistik adalah variabel yang pada analisis bivariat mempunyai nilai $p<0,25$.

3. Melakukan analisis multivariat regresi logistik dengan cara enter, backward, atau forward.

4. Menginterpretasikan model akhir.

Interpretasi utama dari kerangka konsep prediktif adalah mengetahui variabelvariabel apa saja yang berhubungan dengan variabel tergantung.

Setelah dilakukan analisis menggunakan SPSS, maka langkah terakhir adalah menggunakan persamaan yaitu sebagai berikut ( Sopiyudin, 2016):

keterangan:

$$
\mathrm{y}=\alpha+\beta 1 \mathrm{X} 1+\beta 2 \mathrm{X} 2+\beta 3 \mathrm{X} 3+\beta \mathrm{nXn}
$$

$\alpha \quad$ : konstanta

$\beta 1 \quad$ : Koefisien dari varibel independen 1

$\mathrm{X} 1$ : Variabel independen 1

B2 : Koefisien dari varibel independen 2

X2 : Variabel independen 2

$\beta 3 \quad$ : Koefisien dari varibel independen 3

X3 : Variabel independen 3

$\beta n \quad$ : Koefisien dari varibel independen $n$

$\mathrm{Xn} \quad$ : Variabel independen $\mathrm{n}(10)$. 


\section{MIRACLE JOURNAL}

\section{Penyajian Data}

Penyajian data dalam penelitian ini adalah dalam bentuk tabulasi dan tekstual. Dimana tabulasi adalah penyajian data dalam bentuk table yang terdiri dari baris dan kolom, metode ini digunakan untuk memaparkan variabel hasil penelitian sehingga mudah dibaca dan dimengerti. Tekstual yaitu penyajian dalam bentuk kalimat-kalimat / tulisan untuk menerangkan kumpulan data yang diperoleh dimana tekstual dalam penelitian ini sebagai penambah keterangan dari data tabulasi.

\section{Uji Validitas dan Reliabilitas \\ Uji Validitas}

Uji validitas adalah suatu indeks yang menunjukkan alat ukur itu benar - benar mengukur apa yang diukur. Bila seseorang ingin mengukur berat suatu benda maka ia harus menggunakan timbangan. Untuk mengetahui apakah kuesioner yang kita susun mampu mengukur apa yang hendak kita ukur, maka perlu diuji korelasi antar skor (nilai ) tiap-tiap item pertanyaan dengan total skor kuesioner tersebut. Menggunakan rumus korelasi pearson product moment $(r)$, dengan ketentuan jika nilai $r$ hitung $>r$ table,maka pertanyaan valid, dan jika $\mathrm{r}$ hitung < $\mathrm{r}$ table maka pertanyaan tidak valid ( Muhammad, 2015).

\section{Uji Reliabilitas}

Reliabilitas ialah indeks yang menunjukkan sejauh mana suatu alat ukur dapat dipercaya atau dapat diandalkan. Hal ini berarti menunjukkan sejauh mana hasil pengukuran itu tetap konsisten atau tetap asas bila dilakukan pengukuran dua kali atau lebih terhadap gejala yang sama (10). Tingkat reliabilitas dapat dilakukan menggunakan SPSS melalui Uji Cronchbach's Alpha yang dibandingkan dengan tabel r, dengan ketentuan $r$ hitung $>r$ tabel.

\section{Hasil Penelitian \\ Karakteristik Responden}

Tabel 2. Distribusi Frekuensi Karakteristik Responden di Pondok Pesantren Dairi Sidikalang Tahun 2021

\begin{tabular}{|c|c|c|c|}
\hline No & Karakteristik & Frekuensi & Persentase (\%) \\
\hline \multicolumn{4}{|c|}{ Umur } \\
\hline 1 & 10-14 tahun & 75 & 74.3 \\
\hline 2 & 15-17 tahun & 26 & 25.7 \\
\hline & Total & 101 & 100 \\
\hline \multicolumn{4}{|c|}{ Umur Menarche } \\
\hline 1 & 10 Tahun & 3 & 3 \\
\hline 2 & 11 Tahun & 11 & 10.9 \\
\hline 3 & 12 Tahun & 52 & 51.4 \\
\hline 4 & 13 Tahun & 26 & 25.7 \\
\hline 5 & 14 Tahun & 9 & 9 \\
\hline \multicolumn{2}{|r|}{ Total } & 101 & 100 \\
\hline & \multicolumn{3}{|c|}{ Pola Haid } \\
\hline 1 & 28-35 hari & 57 & 56.4 \\
\hline 2 & $<28$ hari dan $>35$ hari & 44 & 43.6 \\
\hline
\end{tabular}


\begin{tabular}{ccccc}
\hline Total & & $\mathbf{1 0 1}$ & $\mathbf{1 0 0}$ \\
\hline & Berdasarkan tabel & 4.1. di atas menunjukkan & bahwa distribusi \\
& & karakteristik
\end{tabular} responden berdasarkan umur adalah 10-14 tahun sebanyak 75 orang (74.3\%) dan 15-17 tahun sebanyak 26 orang $(25.7 \%)$. Berdasarkan umur menarche adalah 10 tahun sebanyak 3 orang (3\%), 11 tahun sebanyak 11 orang (10.9\%), 12 tahun sebanyak 52 orang (51.4\%), 13 tahun sebanyak 26 orang (25.7\%) dan 14 tahun sebanyak 9 orang (9\%). Berdasarkan pola haid adalah 28-35 hari sebanyak 57 orang (56.4\%) dan $<28$ dan $>35$ hari sebanyak 44 orang $(43.6 \%)$.

\section{Pengetahuan Remaja}

Tabel 3. Distribusi Frekuensi Pengetahuan Remaja Putri Saat Menstruasi di Pondok Pesantren Dairi Sidikalang Tahun 2021

\begin{tabular}{llccc}
\hline No & & Pengetahuan & Frekuensi & Persentase (\%) \\
\hline 1 & Kurang & 16 & 15.9 \\
2 & Cukup & 37 & 36.6 \\
3 & Baik & 48 & 47.5 \\
\hline & Total & $\mathbf{1 0 1}$ & $\mathbf{1 0 0}$
\end{tabular}

Berdasarkan tabel 4.2. di atas menunjukkan bahwa distribusi frekuensi pengetahuan remaja putri saat menstruasi adalah kurang sebanyak 16 orang (15.9\%), cukup sebanyak 37 orang (36.6\%) dan baik sebanyak 48 orang $(47.5 \%)$.

\section{Sikap Remaja}

Tabel 4. Distribusi Frekuensi Sikap Remaja Putri Saat Menstruasi di Pondok Pesantren Dairi Sidikalang Tahun 2021

\begin{tabular}{|c|c|c|c|}
\hline No & Sikap & Frekuensi & Persentase (\%) \\
\hline 1 & Kurang Baik & 45 & 44.6 \\
\hline 2 & Baik & 56 & 55.4 \\
\hline & Total & 101 & 100 \\
\hline
\end{tabular}

Berdasarkan tabel 4.3. di atas menunjukkan bahwa distribusi frekuensi sikap remaja putri saat menstruasi adalah kurang baik sebanyak 45 orang $(44.6 \%)$ dan baik sebanyak 56 orang $(55.4 \%)$.

\section{Sumber Informasi Remaja}

Tabel 5. Distribusi Frekuensi Sumber Informasi Remaja Putri Saat Menstruasi di Pondok Pesantren Dairi Sidikalang Tahun 2021

\begin{tabular}{|c|c|c|c|}
\hline No & Sumber Informasi & Frekuensi & Persentase (\%) \\
\hline 1 & Kurang Baik & 66 & 65.3 \\
\hline 2 & Baik & 35 & 34.7 \\
\hline & Total & 101 & 100 \\
\hline
\end{tabular}

Berdasarkan tabel 4.4. di atas menunjukkan bahwa distribusi frekuensi sumber informasi remaja putri saat menstruasi adalah kurang baik sebanyak 66 orang (65.3\%) dan baik sebanyak 35 orang $(34.7 \%)$.

\section{Dukungan Guru/Ustadzah}


Tabel 6. Distribusi Frekuensi Dukungan Guru/Ustadzah Saat Menstruasi di Pondok Pesantren Dairi Sidikalang Tahun 2021

\begin{tabular}{llcc}
\hline No & Dukungan Guru/Ustadzah & Frekuensi & Persentase (\%) \\
\hline 1 & Kurang Mendukung & 63 & 62.4 \\
2 & Mendukung & 38 & 37.6 \\
\hline & Total & $\mathbf{1 0 1}$ & $\mathbf{1 0 0}$ \\
\hline
\end{tabular}

Berdasarkan tabel 4.5. di atas menunjukkan bahwa distribusi frekuensi dukungan guru/ustadzah saat menstruasi adalah kurang mendukung sebanyak 63 orang (62.4\%) dan mendukung sebanyak 38 orang (37.6\%).

Dukungan Keluarga

Tabel 7. Distribusi Frekuensi Dukungan Keluarga Saat Menstruasi di Pondok Pesantren Dairi Sidikalang Tahun 2021

\begin{tabular}{llcc}
\hline No & Dukungan Keluarga & Frekuensi & Persentase (\%) \\
& & & \\
\hline 1 & Kurang Mendukung & 37 & 36.6 \\
2 & Mendukung & 64 & 63.4 \\
\hline & Total & $\mathbf{1 0 1}$ & $\mathbf{1 0 0}$ \\
\hline
\end{tabular}

Berdasarkan tabel 4.6. di atas menunjukkan bahwa distribusi frekuensi dukungan keluarga saat menstruasi adalah kurang mendukung sebanyak 37 orang (36.6\%) dan mendukung sebanyak 64 orang $(63.4 \%)$.

\section{Hygiene Genitalia Remaja Putri}

Tabel 8. Distribusi Frekuensi Hygiene Genitalia Remaja Putri Saat Menstruasi di Pondok Pesantren Dairi Sidikalang Tahun 2021

\begin{tabular}{clcc}
\hline No & Hygiene Genitalia & Frekuensi & Persentase (\%) \\
\hline 1 & Kurang Sesuai & 52 & 51.5 \\
2 & Sesuai & 49 & 48.5 \\
\hline & Total & $\mathbf{1 0 1}$ & $\mathbf{1 0 0}$
\end{tabular}

Berdasarkan tabel 4.7. di atas menunjukkan bahwa distribusi frekuensi hygiene genitalia remaja saat menstruasi adalah kurang sesuai sebanyak 52 orang $(51.5 \%)$ dan sesuai sebanyak 49 orang $(48.5 \%)$.

\section{Analisis Bivariat}

Hubungan Pengetahuan terhadap Hygiene Genitalia Pada Remaja Putri Saat Menstruasi di Pondok Pesantren Dairi Sidikalang Tahun 2021

Tabel 9. Tabulasi Silang Pengetahuan terhadap Hygiene Genitalia Pada Remaja Putri Saat Menstruasi di Pondok Pesantren Dairi Sidikalang Tahun 2021

\begin{tabular}{|c|c|c|c|c|c|c|c|}
\hline \multirow{3}{*}{ Pengetahuan } & \multicolumn{4}{|c|}{ Hygiene Genitalia } & \multirow{2}{*}{\multicolumn{2}{|c|}{ Total }} & \multirow{3}{*}{$P$ value } \\
\hline & \multicolumn{2}{|c|}{$\begin{array}{c}\text { Kurang } \\
\text { Sesuai }\end{array}$} & \multicolumn{2}{|c|}{ Sesuai } & & & \\
\hline & $f$ & $\%$ & $\mathbf{f}$ & $\%$ & $\mathbf{f}$ & $\%$ & \\
\hline Kurang & 15 & 14.9 & 1 & 1 & 16 & 15.9 & \\
\hline Cukup & 19 & 18.8 & 18 & 17.8 & 37 & 36.6 & 0,001 \\
\hline Baik & 18 & 17.8 & 30 & 29.7 & 48 & 47.5 & \\
\hline
\end{tabular}




\begin{tabular}{lllllll}
\hline Total & 52 & 51.5 & 49 & 48.5 & 101 & 100 \\
\hline
\end{tabular}

Berdasarkan tabel 4.8. menunjukkan bahwa hasil tabulasi silang dari 101 orang (100\%) yang memiliki pengetahuan kurang sebanyak 16 orang (15.9\%) dengan hygiene genitalia kurang sesuai sebanyak 15 orang (14.9\%) dan sesuai sebanyak 1 orang (1\%). Berdasarkan pengetahuan cukup sebanyak 37 orang (36.6\%) dengan hygiene genitalia kurang sesuai sebanyak 19 orang (18.8\%) dan sesuai sebanyak 18 orang (17.8\%). Sementara pengetahuan baik sebanyak 48 orang (47.5\%) dengan hygiene genitalia kurang sesuai sebanyak 18 orang (17.8\%) dan sesuai sebanyak 30 orang $(29.7 \%)$.

Dari hasil analisis chi-square di dapatkan bahwa nilai $p$-value sebesar $0,001<\mathrm{sig}$ $\alpha=0,05$. Hasil analisis ini memenuhi kriteria persyaratan hipotesis hubungan, sehingga dapat diketahui bahwa pengetahuan memiliki hubungan signifikan terhadap hygiene genitalia pada remaja putri saat menstruasi di Pondok Pesantren Dairi Sidikalang.

Hubungan Sikap terhadap Hygiene Genitalia Pada Remaja Putri Saat Menstruasi di Pondok Pesantren Dairi Sidikalang Tahun 2021

Tabel 10. Tabulasi Silang Sikap terhadap Hygiene Genitalia Pada Remaja Putri Saat Menstruasi di Pondok Pesantren Dairi Sidikalang Tahun 2021

\begin{tabular}{|c|c|c|c|c|c|c|c|}
\hline \multirow{3}{*}{ Sikap } & \multicolumn{4}{|c|}{ Hygiene Genitalia } & \multirow{2}{*}{\multicolumn{2}{|c|}{ Total }} & \multirow{3}{*}{ P value } \\
\hline & \multicolumn{2}{|c|}{ Kurang Sesuai } & \multicolumn{2}{|c|}{ Sesuai } & & & \\
\hline & $\mathbf{f}$ & $\%$ & $\mathbf{f}$ & $\%$ & $\mathbf{f}$ & $\%$ & \\
\hline Kurang Baik & 31 & 30.7 & 14 & 13.9 & 45 & 44.6 & \\
\hline Baik & 21 & 20.8 & 35 & 34.6 & 56 & 55.4 & 0,003 \\
\hline Total & 52 & 51.5 & 49 & 48.5 & 101 & 100 & \\
\hline
\end{tabular}

Berdasarkan tabel 4.9. menunjukkan bahwa hasil tabulasi silang dari 101 orang (100\%) yang memiliki sikap kurang baik sebanyak 45 orang (44.6\%) dengan hygiene genitalia kurang sesuai sebanyak 31 orang (30.7\%) dan sesuai sebanyak 14 orang (13.9\%). Sementara sikap baik sebanyak 56 orang (55.4\%) dengan hygiene genitalia kurang sesuai sebanyak 21 orang (20.8\%) dan sesuai sebanyak 35 orang (34.6\%).

Dari hasil analisis chi-square di dapatkan bahwa nilai $p$-value sebesar $0,003<$ sig $\alpha=0,05$. Hasil analisis ini memenuhi kriteria persyaratan hipotesis hubungan, sehingga dapat diketahui bahwa sikap memiliki hubungan signifikan terhadap hygiene genitalia pada remaja putri saat menstruasi di Pondok Pesantren Dairi Sidikalang.

Hubungan Sumber Informasi terhadap Hygiene Genitalia Pada Remaja Putri Saat Menstruasi di Pondok Pesantren Dairi Sidikalang Tahun 2021

Tabel 11. Tabulasi Silang Sumber Informasi terhadap Hygiene Genitalia Pada Remaja Putri Saat Menstruasi di Pondok Pesantren Dairi Sidikalang Tahun 2021

\begin{tabular}{|c|c|c|c|c|c|c|c|}
\hline \multirow{3}{*}{ Sumber Informasi } & \multicolumn{4}{|c|}{ Hygiene Genitalia } & \multirow{2}{*}{\multicolumn{2}{|c|}{ Total }} & \multirow{3}{*}{ P value } \\
\hline & \multicolumn{2}{|c|}{ Kurang Sesuai } & \multicolumn{2}{|c|}{ Sesuai } & & & \\
\hline & f & $\%$ & f & $\%$ & f & $\%$ & \\
\hline Kurang Baik & 39 & 38.6 & 27 & 26.7 & 66 & 65.3 & \\
\hline Baik & 13 & 12.9 & 22 & 21.8 & 35 & 34.7 & 0,059 \\
\hline Total & 52 & 51.5 & 49 & 48.5 & 101 & 100 & \\
\hline
\end{tabular}

Berdasarkan tabel 4.10. menunjukkan bahwa hasil tabulasi silang dari 101 orang (100\%) yang memiliki sumber infromasi kurang baik sebanyak 66 orang (65.3\%) dengan 
hygiene genitalia kurang sesuai sebanyak 39 orang (38.6\%) dan sesuai sebanyak 27 orang (26.7\%). Sementara sumber informasi baik sebanyak 35 orang $(34.7 \%)$ dengan hygiene genitalia kurang sesuai sebanyak 13 orang (12.9\%) dan sesuai sebanyak 22 orang $(21.8 \%)$.

Dari hasil analisis chi-square di dapatkan bahwa nilai $p$-value sebesar $0,059<$ sig $\alpha=0,05$. Hasil analisis ini memenuhi kriteria persyaratan hipotesis hubungan, sehingga dapat diketahui bahwa sumber informasi tidak memiliki hubungan signifikan terhadap hygiene genitalia pada remaja putri saat menstruasi di Pondok Pesantren Dairi Sidikalang Hubungan Dukungan Guru/ustadzah terhadap Hygiene Genitalia Pada Remaja Putri Saat Menstruasi di Pondok Pesantren Dairi Sidikalang Tahun 2021

Tabel 12. Tabulasi Silang Dukungan Guru/ustadzah terhadap Hygiene Genitalia Pada Remaja Putri Saat Menstruasi di Pondok Pesantren Dairi Sidikalang Tahun 2021

\begin{tabular}{|c|c|c|c|c|c|c|c|}
\hline \multirow{3}{*}{$\begin{array}{c}\text { Dukungan } \\
\text { Guru/ustadzah }\end{array}$} & \multicolumn{4}{|c|}{ Hygiene Genitalia } & \multirow{2}{*}{\multicolumn{2}{|c|}{ Total }} & \multirow{3}{*}{$P$ value } \\
\hline & \multicolumn{2}{|c|}{ Kurang Sesuai } & \multicolumn{2}{|c|}{ Sesuai } & & & \\
\hline & f & $\%$ & $\mathbf{f}$ & $\%$ & f & $\%$ & \\
\hline Kurang Mendukung & 38 & 37.6 & 25 & 24.8 & 63 & 62.4 & \\
\hline Mendukung & 14 & 13.9 & 24 & 23.7 & 38 & 37.6 & 0,037 \\
\hline Total & 52 & 51.5 & 49 & 48.5 & 101 & 100 & \\
\hline
\end{tabular}

Berdasarkan tabel 4.11. menunjukkan bahwa hasil tabulasi silang dari 101 orang (100\%) yang memiliki dukungan guru/ustadzah kurang mendukung sebanyak 63 orang $(62.4 \%)$ dengan hygiene genitalia kurang sesuai sebanyak 38 orang $(37.6 \%)$ dan sesuai sebanyak 25 orang $(24.8 \%)$. Sementara dukungan guru/ustadzah mendukung sebanyak 38 orang $(37.6 \%)$ dengan hygiene genitalia kurang sesuai sebanyak 14 orang (13.9\%) dan sesuai sebanyak 24 orang $(23.7 \%)$.

Dari hasil analisis chi-square di dapatkan bahwa nilai p-value sebesar 0,037<sig $\alpha=0,05$. Hasil analisis ini memenuhi kriteria persyaratan hipotesis hubungan, sehingga dapat diketahui bahwa dukungan guru/ustadzah memiliki hubungan signifikan terhadap hygiene genitalia pada remaja putri saat menstruasi di Pondok Pesantren Dairi Sidikalang.

Hubungan Dukungan Keluarga terhadap Hygiene Genitalia Pada Remaja Putri Saat Menstruasi di Pondok Pesantren Dairi Sidikalang Tahun 2021

Tabel 13. Tabulasi Silang Dukungan Keluarga terhadap Hygiene Genitalia Pada Remaja Putri Saat Menstruasi di Pondok Pesantren Dairi Sidikalang Tahun 2021

\begin{tabular}{|c|c|c|c|c|c|c|c|}
\hline \multirow{3}{*}{ Dukungan Keluarga } & \multicolumn{4}{|c|}{ Hygiene Genitalia } & \multirow{2}{*}{\multicolumn{2}{|c|}{ Total }} & \multirow{3}{*}{ P value } \\
\hline & \multicolumn{2}{|c|}{ Kurang Sesuai } & \multicolumn{2}{|c|}{ Sesuai } & & & \\
\hline & $\mathbf{f}$ & $\%$ & f & $\%$ & f & $\%$ & \\
\hline Kurang Mendukung & 24 & 23.8 & 13 & 12.9 & 37 & 36.7 & \\
\hline Mendukung & 28 & 27.7 & 36 & 35.6 & 64 & 63.3 & 0,066 \\
\hline Total & 52 & 51.5 & 49 & 48.5 & 101 & 100 & \\
\hline
\end{tabular}

Berdasarkan tabel 4.12. menunjukkan bahwa hasil tabulasi silang dari 101 orang (100\%) yang memiliki dukungan keluarga kurang mendukung sebanyak 37 orang (36.6\%) dengan hygiene genitalia kurang sesuai sebanyak 24 orang $(23.8 \%)$ dan sesuai sebanyak 13 orang (12.9\%). Sementara dukungan keluarga mendukung sebanyak 64 
orang (63.4\%) dengan hygiene genitalia kurang sesuai sebanyak 28 orang (27.7\%) dan sesuai sebanyak 36 orang (35.6\%).

Dari hasil analisis chi-square di dapatkan bahwa nilai p-value sebesar 0,066 <sig $\alpha=0,05$. Hasil analisis ini memenuhi kriteria persyaratan hipotesis hubungan, sehingga dapat diketahui bahwa dukungan keluarga tidak memiliki hubungan signifikan terhadap hygiene genitalia pada remaja putri saat menstruasi di Pondok Pesantren Dairi Sidikalang.

\section{Analisis Multivariat}

Hasil Seleksi Kandidat Multivariat

Tabel 14. Seleksi Variabel yang Menjadi Kandidat Model dalam Uji Regresi Logistik

\begin{tabular}{clcc} 
& \multicolumn{2}{c}{ Berdasarkan Analisis Bivariat } \\
\hline No & & Variabel & $\boldsymbol{p}$ value (sig) \\
\hline 1 & Pengetahuan & 0,001 \\
2 & Sikap & 0,003 \\
3 & Sumber informasi & 0,059 \\
4 & Dukungan Guru/Ustadzah & 0,037 \\
5 & Dukungan Keluarga & 0,066
\end{tabular}

Tabel 4.12. menunjukkan semua variabel memiliki $\mathrm{p}$ value $<0,25$. Dengan demikian ke 5 (lima) variabel tersebut layak masuk ke model multivariat.

\section{Hasil Uji Analisis Multivariat}

Tabel 15.

Hasil Analisis Regresi Logistic Berganda Tahap Pertama

\begin{tabular}{|c|c|c|c|c|c|c|}
\hline \multirow{2}{*}{ No } & \multirow{2}{*}{ Variabel } & \multirow{2}{*}{ B } & \multirow{2}{*}{$p($ Sig $)$} & \multirow{2}{*}{$\operatorname{Exp}(\mathbf{B})$} & \multicolumn{2}{|c|}{ 95\% C.I } \\
\hline & & & & & Lower & Upper \\
\hline 1 & Pengetahuan & 3.144 & 0.011 & 23.205 & 2.047 & 263.024 \\
\hline 2 & Sikap & 1.499 & 0.005 & 4.476 & 1.571 & 12.749 \\
\hline 3 & Sumber Informasi & 1.492 & 0.009 & 4.446 & 1.447 & 13.663 \\
\hline 4 & $\begin{array}{l}\text { Dukungan } \\
\text { Guru/Ustadzah }\end{array}$ & 1.297 & 0.015 & 3.660 & 1.290 & 10.387 \\
\hline 5 & $\begin{array}{l}\text { Dukungan } \\
\text { Keluarga }\end{array}$ & -0.020 & 0.971 & 0.981 & 0.336 & 2.858 \\
\hline & Constant & -4.623 & 0.000 & 0.010 & & \\
\hline
\end{tabular}

Berdasarkan tabel 4.14. diatas dapat dilihat bahwa analisis uji regresi logistic yang diseleksi adalah variabel dukungan keluarga dengan nilai $p$ (sig) sebesar 0.971, sehingga di dapatkan hasil uji seleksi logistic berganda tahap kedua yang dapat dilihat pada tabel di bawah ini:

Tabel 16.

Hasil Analisis Regresi Logistic Berganda Tahap Kedua

\begin{tabular}{|c|c|c|c|c|c|c|}
\hline \multirow{2}{*}{ No } & \multirow{2}{*}{ Variabel } & \multirow{2}{*}{ B } & \multirow{2}{*}{$p($ Sig $)$} & \multirow{2}{*}{$\operatorname{Exp}(B)$} & \multicolumn{2}{|c|}{ 95\% C.I } \\
\hline & & & & & Lower & Upper \\
\hline 1 & Pengetahuan & 3.132 & 0.008 & 22.920 & 2.231 & 235.477 \\
\hline 2 & Sikap & 1.498 & 0.005 & 4.471 & 1.573 & 12.707 \\
\hline 3 & Sumber Informasi & 1.488 & 0.008 & 4.428 & 1.474 & 13.306 \\
\hline 4 & $\begin{array}{l}\text { Dukungan } \\
\text { Guru/Ustadzah }\end{array}$ & 1.293 & 0.013 & 3.645 & 1.316 & 10.099 \\
\hline
\end{tabular}


Berdasarkan tabel 4.13. di atas menunjukkan bahwa ada empat variabel yang berpengaruh terhadap hygiene genitalia pada remaja putri saat menstruasi yaitu sebagai berikut:

1. Variabel pengetahuan dengan $p($ sig $=0.008)$ OR 22.9 CI 2.231-235.477 dengan nilai koefisien B yaitu 3.132 bernilai positif, maka semakin baik pengetahuan remaja putri maka akan semakin baik pula hygiene genitalia saat menstruasi.

2. Variabel sikap dengan $p$ (sig=0.005) OR 4.47 CI 1.573-12.707 dengan nilai koefisien B yaitu 1.498 bernilai positif, maka semakin baik sikap remaja putri maka akan semakin baik pula hygiene genitalia saat menstruasi.

3. Variabel sumber informasi dengan $p$ (sig=0.008) OR 4.42 CI 1.474-13.306 dengan nilai koefisien B yaitu 1.488 bernilai positif, maka semakin baik sumber informasi remaja putri maka akan semakin baik pula hygiene genitalia saat menstruasi.

4. Variabel dukungan guru/ustadzah dengan $p$ (sig=0.013) OR 3.6 CI 1.316-10.099 dengan nilai koefisien B yaitu 1.293 bernilai positif, maka semakin baik dukungan guru/ustadzah remaja putri maka akan semakin baik pula hygiene genitalia saat menstruasi.

5. Variabel paling dominan memiliki pengaruh signifikan terhadap hygiene genitalia saat menstruasi adalah pengetahuan dengan $p$ (sig) sebesar 0,008 dengan OR 22.9 artinya remaja putri yang memiliki pengetahuan baik berpeluang 22.9 kali hygiene genitalia baik. Nilai koefisien B yaitu 3.132 bernilai positif maka semakin baik pengetahuan remaja putri maka akan semakin baik pula hygiene genitalia saat menstruasi.

\section{Pembahasan}

\section{Pengaruh Pengetahuan terhadap Hygiene Genitalia Pada Remaja Putri Saat Menstruasi di Pondok Pesantren Dairi Sidikalang Tahun 2021}

Dari hasil analisis chi-square di dapatkan bahwa nilai $p$-value sebesar $0,001<$ sig $\alpha=0,05$. Hasil analisis ini memenuhi kriteria persyaratan hipotesis hubungan, sehingga dapat diketahui bahwa pengetahuan memiliki hubungan signifikan terhadap hygiene genitalia pada remaja putri saat menstruasi di Pondok Pesantren Dairi Sidikalang. Sementara dari analisis multivariat dengan uji regresi logistic di dapatkan bahwa ada pengaruh pengetahuan terhadap hygiene genitalia pada remaja putri saat menstruasi dengan nilai $p$ (sig) sebesar 0.008 OR 22.9 CI 2.231-235.477 dengan nilai koefisien B yaitu 3.132 bernilai positif, maka semakin baik pengetahuan remaja putri maka akan semakin baik pula hygiene genitalia saat menstruasi.

Menurut asumsi peneliti hygiene genitalia berkaitan dengan cara atau tindakan untuk menjaga dan mencegah terjadinya penyakit pada organ genitalia atau reproduksi. Pada masa remaja terjadi banyak perubahan tubuhnya karena adanya perkembangan termasuk pada organ reproduksi menuju tahap kematangan baik secara fisiologis untuk mampu berfungsi sesuai dengan tahapannya. Menurut Indriastuti dalam penelitian Bujawati dkk menyatakan bahwa personal hygiene pada saat menstruasi tidak terjadi begitu saja namun merupakan sebuah proses yang dipelajari, dalam artian pengetahuan dapat terbentuk dari proses pembelajaran baik dari orang lain, lingkungan bahkan media cetak yang akan mempengaruhi tingkat pengetahuan seseorang apalagi remaja yang merupakan masa peralihan yang dapat mudah terpapar pada informasi yang baik ataupun tidak baik. Dapat dilihat dari data yang menunjukkan remaja dengan tingkat pengetahuan 


\section{MIRACLE JOURNAL}

cukup sebanyak 37 orang (36.6\%) dengan hygiene genitalia kurang sesuai sebanyak 19 orang $(18.8 \%)$ dan sesuai sebanyak 18 orang (17.8\%). Adanya data ini memperlihatkan bahwa remaja pada masa ini daya analisanya masih sangat terbatas pada tingkat tahu sehingga dalam menyampaikan informasi harus dilakukan secara berulang-ulang, karena pada masa ini remaja mudah terpapar informasi dari lingkungannya seperti teman sebayanya dan apabila temannya memberikan informasi yang salah dan benar dia akan mudah terpengaruh dan menunjukkan perilaku sesuai dengan yang teman sebanyanya ucapkan baik hygiene genitalia sesuai atau kurang sesuai.

Akibat kurangnya media informasi baik cetak dan elektronik menyebabkan remaja kurang memahami hygiene genitalia. Dengan kurangnya informasi baik dari media cetak, elektronik maupun dari guru/ustadzah mengakibatkan rendahnya pengetahuan remaja. Dapat dilihat dari pengetahuan kurang sebanyak 16 orang (15.9\%) dengan hygiene genitalia kurang sesuai sebanyak 15 orang (14.9\%) dan sesuai sebanyak 1 orang $(1 \%)$. Rendahnya pengetahuan akan berdampak pada tindakan hygiene genitalia remaja, namun dari data juga menunjukkan bahwa di temukan 1 orang dengan hygiene genitalia sesuai yang disebabkan karena adanya pengaruh dari lingkungannya seperti teman yang melakukan hygiene genitalia yang benar selama menstruasi sehingga remaja mengikutinya walaupun kondisi dari pengetahuannya masih sangat kurang.

\section{Pengaruh Sikap terhadap Hygiene Genitalia Pada Remaja Putri Saat Menstruasi di Pondok Pesantren Dairi Sidikalang Tahun 2021}

Dari hasil analisis chi-square di dapatkan bahwa nilai p-value sebesar $0,003<$ sig $\alpha=0,05$. Hasil analisis ini memenuhi kriteria persyaratan hipotesis hubungan, sehingga dapat diketahui bahwa sikap memiliki hubungan signifikan terhadap hygiene genitalia pada remaja putri saat menstruasi di Pondok Pesantren Dairi Sidikalang. Sementara dari analisis multivariat dengan uji regresi logistic di dapatkan bahwa ada pengaruh sikap terhadap hygiene genitalia pada remaja putri saat menstruasi dengan nilai $p$ (sig) sebesar 0.005 OR 4.47 CI 1.573-12.707 dengan nilai koefisien B yaitu 1.498 bernilai positif, maka semakin baik sikap remaja putri maka akan semakin baik pula hygiene genitalia saat menstruasi.

Penelitian ini sejalan dengan Linda Suryani (2020) di SMP Negeri 12 Kota Pekanbaru bahwa hasil sikap ( $\mathrm{P}$ value 0,000$)$ mempengaruhi perilaku remaja putri tentang personal hygiene pada saat menstruasi (15). Dalam penelitian yang dilakukan oleh Putri Diah Pemilian, Winda Agustina, Desna Verayanti (2019) di Di SMA Etidlandia Medan Tahun 2018 menunjukkan bahwa ada hubungan sikap $(0,049)$ dengan Personal Hygiene saat Menstruasi ( Pemiliana, 2019).

Namun dari data juga di dapatkan sebanyak $45(44,6 \%)$ remaja yang bersikap kurang baik di temukan sebanyak 14 orang $(13.9 \%)$ melakukan hygiene genitalia yang sesuai. Hal ini bisa terjadi karena adanya efek komunikasi sosial yang terjadi pada remaja, walaupun dia tidak menerima informasi dan menyikapi nya dengan acuh tak acuh, namun karena adanya orang yang menegur dan memperlihatkan contoh yang baik maka ia mengikutinya. Hal ini sesuai dengan ciri-ciri remaja bahwa akan lebih banyak mendengar dan berinteraksi dengan teman sebaya sebagai suatu proses perkembangan sosial remaja. Dalam penelitian Desmita yang di kutip oleh Bujawati, dkk (2017) bahwa perkembangan kehidupan sosial remaja ditandai dengan meningkatnya pengaruh teman sebaya. Remaja lebih banyak menghabiskan waktunya untuk berinteraksi sosial dengan teman sebayanya. Teman sebaya memberikan pengaruh yang besar terhadap sikap, minat, penampilan dan perilaku remaja. Hal tersebut dikarenakan komunikasi diantara teman 


\section{MIRACLE JOURNAL}

sebaya lebih mudah dicerna dan diterima daripada komunikasi dengan orang tua atau yang lebih dewasa daripada remaja.

\section{Pengaruh Sumber Informasi terhadap Hygiene Genitalia Pada Remaja Putri Saat Menstruasi di Pondok Pesantren Dairi Sidikalang Tahun 2021}

Dari hasil analisis chi-square di dapatkan bahwa nilai $p$-value sebesar 0,059<sig $\alpha=0,05$. Hasil analisis ini memenuhi kriteria persyaratan hipotesis hubungan, sehingga dapat diketahui bahwa sumber informasi tidak memiliki memiliki hubungan signifikan terhadap hygiene genitalia pada remaja putri saat menstruasi di Pondok Pesantren Dairi Sidikalang. Sementara dari analisis multivariat dengan uji regresi logistic di dapatkan bahwa ada pengaruh sumber informasi terhadap hygiene genitalia pada remaja putri saat menstruasi dengan nilai $p$ (sig) sebesar 0.008 OR 4.42 CI 1.474-13.306 dengan nilai koefisien B yaitu 1.488 bernilai positif, maka semakin baik sumber informasi maka akan semakin baik pula hygiene genitalia saat menstruasi.

Menurut asumsi peneliti sumber informasi memiliki keterkaitan dengan perubahan perilaku remaja dalam melakukan hygiene genitalia yang didapatkan langsung dari lingkungan sekitarnya dimana dia melakukan aktivitas sehari-harinya. Peran orang tua berkontribusi positif terhadap perilaku remaja karena orang tua merupakan sumber utama yang dekat dengan remaja, sehingga orang tua terutama ibu harus memiliki pengetahuan yang baik mengenai menstruasi dan hygiene genitalia sebagai dasar penting di tanamkan kepada remaja sehingga dia sudah ada bekal untuk melakukan hygiene genitalia. Sumber informasi lainnya adalah guru yang merupakan kelanjutan dari tangan kedua orang tua dalam memberikan pemahaman mengenai informasi. Kedua sumber ini akan menjadi sebuah dasar untuk membentuk perilaku yang baik dalam melindungi remaja agar tidak terpapar pada informasi yang tidak baik melalui media sosial lainnya. Dapat dilihat dari sumber informasi baik sebanyak 35 orang $(34.7 \%)$ dengan hygiene genitalia kurang sesuai sebanyak 13 orang (12.9\%) dan sesuai sebanyak 22 orang $(21.8 \%)$.

Sumber informasi yang kurang baik akan berpengaruh terhadap praktik hygiene genitalia karena hanya dengan informasi yang baiklah maka remaja dapat terbantu dalam melakukan praktik hygiene yang baik dan benar. Sumber informasi dapat menjadi sebuah permasalahan apabila remaja mendapatkan informasi yang kurang baik misalnya ibu kurang menjelaskan mengenai menstruasi kepada remaja sehingga remaja yang memang pada prosesnya adalah masa peralihan dan adaptasi dapat menjadi bingung mengenai kondisinya saat menstruasi terutama anak yang mengalami menarche di rumahnya. Dapat dilihat dari data yang menunjukkan sumber infromasi kurang baik sebanyak 66 orang (65.3\%) dengan hygiene genitalia kurang sesuai sebanyak 39 orang (38.6\%) dan sesuai sebanyak 27 orang $(26.7 \%)$.

\section{Pengaruh Dukungan Guru/Ustadzah terhadap Hygiene Genitalia Pada Remaja Putri Saat Menstruasi di Pondok Pesantren Dairi Sidikalang Tahun 2021}

Dari hasil analisis chi-square di dapatkan bahwa nilai $p$-value sebesar $0,037<$ sig $\alpha=0,05$. Hasil analisis ini memenuhi kriteria persyaratan hipotesis hubungan, sehingga dapat diketahui bahwa dukungan guru/ustadzah memiliki hubungan signifikan terhadap hygiene genitalia pada remaja putri saat menstruasi di Pondok Pesantren Dairi Sidikalang. Sementara dari analisis multivariat dengan uji regresi logistic di dapatkan bahwa ada pengaruh dukungan guru/ustadzah terhadap hygiene genitalia pada remaja putri saat menstruasi dengan nilai $p$ (sig) sebesar 0.013 OR 3.6 CI 1.316-10.099 dengan nilai koefisien B yaitu 1.293 bernilai positif, maka semakin baik dukungan guru/ustadzah maka akan semakin baik pula hygiene genitalia saat menstruasi. 


\section{MIRACLE JOURNAL}

Penelitian ini sejalan dengan Dea Amanda, Fajar Ariyanti (2020) di Pondok Pesantren Modern Kota Depok yang menunjukkan bahwa terdapat hubungan antara dukungan ustadzah ( $\mathrm{p}$-value $=0,007)$ dengan perilaku menstrual hygiene santriwati ( Amanda dan Ariyanti, 2020).

Guru adalah orang yang memiliki kredibilitas tertentu (telah menempuh kompetensi pendidikan untuk mengajar) untuk memberikan pendidikan, bimbingan dan pengembangan kreatifitas bagi anak yang sedang belajar di sekolah. Guru merupakan orang yang sangat berarti karena mempunyai nilai-nilai yang ideal bagi anak remaja dan mempunyai pengaruh cukup besar bagi perkembangan identitas diri karena dalam usia sekolah anak sedang mencari model. Pendidikan kesehatan terutama pendidikan reproduksi dalam hal ini materi tentang menstruasi hendaknya tidak dipisahkan dari pendidikan umum lainnya. Pendidikan reproduksi dimasukan dalam pelajaran ilmu biologi, kesehatan, moral dan etika secara bertahap dan terus menerus.

Menurut asumsi peneliti bahwa dukungan berkaitan dengan pemberian bantuan baik informasional, emosional dan praktikal yang diberikan guru kepada muridnya. Di dalam sekolah umum remaja tidak begitu banyak terpapar dengan informasi mengenai hygiene dan menstruasi tetapi secara teorikal mereka mendapatkan informasi seputar kesehatan reproduksi sehingga mereka akan dapat mengaplikasinnya dengan bantuan keluarga. Namun berbeda dengan remaja yang berada di pondok pesantren yang lebih banyak melakukan interaksi sosial dengan guru/ustadzah dan teman sebaya.

Dukungan sosial yang tidak baik dari lingkungan remaja termasuk guru/ustadzah pada remaja berdampak secara positif dalam memengaruhi perilaku remaja untuk melaksanakan hygiene genitalia yang sesuai dengan kondisi sebenarnya. Dapat dilihat dari data yang menunjukkan bahwa dukungan guru/ustadzah kurang mendukung sebanyak 63 orang $(62.4 \%)$ dengan hygiene genitalia kurang sesuai sebanyak 38 orang (37.6\%) dan sesuai sebanyak 25 orang $(24.8 \%)$. Kurangnya dukungan guru atau ustadzah sebagai orang terdekat kedua remaja membuat remaja yang awalnya tidak mengetahui informasi mengenai menstruasi dan hygiene genitalia karena belum mendapat bekal dari orang tua menyebabkan remaja akan salah dalam informasi dan hanya meniru dari sekitarnya tanpa melibatkan kebenaran perilaku tersebut, sementara anak remaja yang sudah ada bekal mengenai informasi menstruasi dari orang tuanya tidak melakukan praktik hygiene genitalia karena guru kurang memperhatikan mereka, anak terpapar pada praktik yang tidak benar karena praktik yang tidak benar akan lebih mudah di aplikasikan daripada praktik yang sebenarnya, artinya kesadaran anak sudah mulai terpecah karena pengaruh temannya dalam melakukan hygiene genitalia yang benar.

\section{Pengaruh Dukungan Keluarga terhadap Hygiene Genitalia Pada Remaja Putri Saat Menstruasi di Pondok Pesantren Dairi Sidikalang Tahun 2021}

Dari hasil analisis chi-square di dapatkan bahwa nilai $p$-value sebesar $0,066<$ sig $\alpha=0,05$. Hasil analisis ini memenuhi kriteria persyaratan hipotesis hubungan, sehingga dapat diketahui bahwa dukungan keluarga tidak memiliki hubungan signifikan terhadap hygiene genitalia pada remaja putri saat menstruasi di Pondok Pesantren Dairi Sidikalang. Sementara dari analisis multivariat dengan uji regresi logistic di dapatkan bahwa tidak ada pengaruh dukungan keluarga terhadap hygiene genitalia pada remaja putri saat menstruasi dengan nilai $p$ (sig) sebesar 0.971 OR 0.9 CI 0.336-2.858 dengan nilai koefisien B yaitu -0.020 bernilai negatif, maka semakin negatif dukungan keluarga maka akan semakin tidak baik pula hygiene genitalia saat menstruasi.

Penelitian ini tidak sejalan dengan Sutriyani, Maria Paula, Marla Nahak Erna Febriyanti S.Kep (2020) yang menunjukkan bahwa ada hubungan antara dukungan 


\section{MIRACLE JOURNAL}

keluarga remaja putri di SMAN 6 Kupang dengan perilaku perawatan organ reproduksi ( $\mathrm{p}=0,000)$ (Sutriyani, dkk, 2020).

Keluarga merupakan sebagai lembaga sosial yang mempunyai fungsi tradisional keluarga seperti fungsi sosial ekonomi, karena sebagian hasil kerja yang dilakukan di dalam atau di luar rumah dikelola dalam keluarga, yang ditunjukkan dengan adanya pembentukan kerabat, keturunan dan hubungan sosial melalui keluarga dan fungsi proses pendidikan termasuk di dalamnya penanaman nilai dan ideologi kepada anggota keluarga, oleh karena itu penanganan yang baik terhadap persoalan-persoalan keluarga akan memberikan kontribusi yang positif bagi upaya kesehatan para anggotanya ( Notosoedirdjo, 2007).

Dukungan keluarga adalah suatu keadaan yang bermanfaat bagi individu yang diperoleh dari orang lain yang dapat dipercaya, sehingga seseorang akan tahu bahwa ada orang lain yang memperhatikan, menghargai dan mencintainya. Dukungan keluarga juga diartikan sebagai sesuatu bantuan yang dapat diberikan kepada anggota keluarga lain berupa barang, jasa, informasi dan nasehat yang mampu membuat penerima dukungan akan merasa disayang, dihargai, dan tenteram. Menurut asumsi peneliti tidak ada hubungan dan pengaruh baik secara bivariat dan multivariat dikaitkan dengan kondisi dan lingkungan remaja putri yang berada di pondok pesantren, sehingga besar pengaruh yang membentuk perilaku remaja dalam hygiene genitalia di pengaruhi oleh guru atau ustadzah dan teman sebayanya. Adanya keterbatasan komunikasi dalam berhubungan dengan orang tua membuat anak secara global atau meyeluruh berada pada tangan guru atau ustadzahnya bahkan teman sebanyanya. Oleh karena itu adanya perbedaan hasil temuan penelitian dengan penelitian sebelumnya memperlihatkan gambaran yang berbeda.

\section{Pengaruh Yang Paling Dominan Terhadap Hygiene Genitalia Pada Remaja Putri Saat Menstruasi Di Pondok Pesantren Dairi Sidikalang Tahun 2021}

Variabel paling dominan memiliki pengaruh signifikan terhadap hygiene genitalia saat menstruasi adalah pengetahuan dengan $p$ (sig) sebesar 0,008 dengan OR 22.9 artinya remaja putri yang memiliki pengetahuan baik berpeluang 22.9 kali hygiene genitalia baik. Nilai keofisien B yaitu 3.132 bernilai positif maka semakin baik pengetahuan remaja putri maka akan semakin baik pula hygiene genitalia saat menstruasi.

Menurut asumsi peneliti pengetahuan dapat memberikan kontribusi dalam menyikapi adanya masukan dari inforamsi lain yang didapatkan oleh remaja sehingga dengan kuatnya pengetahuan maka ia tidak mudah terpengaruh dari perilaku yang tidak baik mengenai menstruasi dan hygiene genitalia yang kurang baik bahkan remaja mampu untuk memberikan bantuan kepada temannya mengenai pemahaman dan aplikasi menstruasi terhadap temannya. Teman merupakan faktor eksternal yang cukup erat berhubungan dengan praktik personal hygiene saat menstruasi. Lingkungan dan sosial sebagai faktor eksternal sangat mendukung terhadap perubahan praktik personal hygiene individu, dikarenakan lingkungan sebagai tempat perilaku individu, dengan demikian maka akan terbentuk sebuah grup remaja untuk melakukan hygiene genitalia yang baik.

\section{Keterbatasan Penelitian}

Keterbatasan penelitian yang di dapatkan adalah untuk mengetahui dan menganalisis perilaku remaja menggunakan metode cross sectional yang sebatas menganalisa korelasi antara variabel independen dan variabel dependen sehingga data yang di teliti menunjukkan gejala perilaku yang sedang berlangsung sementara data sebab akibat terjadinya perilaku hygiene saat menstruasi tidak di teliti.

\section{Kesimpulan}




\section{MIRACLE JOURNAL}

Berdasarkan hasil penelitian yang berjudul "Faktor-Faktor Yang Memengaruhi Hygiene Genitalia Pada Remaja Putri Saat Menstruasi Di Pondok Pesantren Dairi Sidikalang Tahun 2021", maka dapat disimpulkan, ada pengaruh pengetahuan terhadap Hygiene Genitalia Pada Remaja Putri Saat Menstruasi di Pondok Pesantren Dairi Sidikalang Tahun 2021, ada pengaruh sikap terhadap Hygiene Genitalia Pada Remaja Putri Saat Menstruasi di Pondok Pesantren Dairi Sidikalang Tahun 2021, ada pengaruh sumber informasi terhadap Hygiene Genitalia Pada Remaja Putri Saat Menstruasi di Pondok Pesantren Dairi Sidikalang Tahun 2021, ada pengaruh dukungan guru/ustadzah terhadap Hygiene Genitalia Pada Remaja Putri Saat Menstruasi di Pondok Pesantren Dairi Sidikalang Tahun 2021, ada pengaruh dukungan keluarga terhadap Hygiene Genitalia Pada Remaja Putri Saat Menstruasi di Pondok Pesantren Dairi Sidikalang Tahun 2021, dan variabel paling dominan memiliki pengaruh signifikan terhadap hygiene genitalia saat menstruasi adalah pengetahuan dengan $p$ (sig) sebesar 0,008 dengan OR 22.9 artinya remaja putri yang memiliki pengetahuan baik berpeluang 22.9 kali hygiene genitalia baik. Nilai keofisien B yaitu 3.132 bernilai positif maka semakin baik pengetahuan remaja putri maka akan semakin baik pula hygiene genitalia saat menstruasi.

\section{Daftar Pustaka}

Amanda D, Ariyanti F. (2020) PERILAKU MENSTRUAL HYGIENE REMAJA: STUDI PADA SANTRIWATI DI PONDOK PESANTREN MODERN KOTA DEPOK. J Publ Kesehat Masy Indones.7(2).

Gustina E, Djannah SN. Sumber informasi dan pengetahuan tentang menstrual hygiene pada remaja putri. KEMAS J Kesehat Masyarakat. 10(2):147-52.

Hasil Sensus Penduduk 2020. Jakarta: Badan Pusat Statistik.

I. M. Muhammad I. (2015). Pemanfaatan SPSS dalam penelitian bidang kesehatan dan umum. 5th ed. Suroyo RB, editor. Bandung: Citapustaka media perintis.

Irianto K. (2015). Kesehatan Reproduksi Reproduktive Health Teori dan Praktikum. Bandung: Alfabeta.

Notoatmodjo S. (2012). Metodologi Penelitian Kesehatan. jakarta: Rineka Cipta.

Notosoedirdjo M. (2007). Kesehatan Mental, Konsep Dan Penerapan. Malang: UMM Press.

Noviana N. (2016) Konsep HIV/AIDS Seksualitas dan Kesehatan Reproduksi. Jakarta: Trans Info Media.

Novianti N, Erawan PE, Yasnani Y. (2017). Hubungan Pengetahuan, Sikap, dan Tindakan dengan Personal Hygiene Menstruasi pada Rmaja Putri di SMP Negeri Satap Bukit Asri Kabupaten Buton Tahun 2016. (Jurnal Ilm Mhs Kesehat Masyarakat). 1(3).

Pangribowo Supriyono (2019). BEBAN KANKER DI INDONESIA. Jakarta Selatan: Infodatin Kementerian Kesehatan RI Pusat Data dan Informas. 


\section{MIRACLE JOURNAL}

Pemiliana PD. (2019). Perilaku Remaja Putri dengan Personal Hygiene saat Menstruasi di SMA Etidlandia Medan Tahun 2018. Gaster. 17(1):62-76.

Soekidjo Notoatmodjo. (2012). Metodologi penelitian kesehatan. Jakarta: Rineka Cipta.

Sopiyudin DM. (2016). Analisis Multivariat Regresi Logistik disertai Praktik dengan Program SPSS dan Stata. Jakarta Timur: PT Epidemiologi indonesia.

Sudigdo S dan SI. (2011). Dasar-Dasar Metodologi Klinis Edisi Ke-4. In: Dasar-Dasar Metodologi Klinis Edisi Ke-4.

Suryani L. (2019). Faktor-Faktor yang Mempengaruhi Perilaku Remaja Putri Tentang Personal Hygiene pada Saat Menstruasi dI SMP Negeri 12 Kota Pekanbaru. JOMIS (Journal Midwifery Sci.. 3(2):68-79.

SUTRIYANI S, Nahak MPM, Febriyanti E. (2020). FAKTOR DETERMINAN PERILAKU PERAWATAN ORGAN REPRODUKSI REMAJA PUTRI DI SMA NEGERI 6 KUPANG. UNIVERSITAS CITRA BANGSA.

Swarjana IK. (2015). Metodologi Penelitian Kesehatan (Edisi Revisi). Bendatu M, editor. Yogyakarta: Andi Offset.

WHO, (2020). Human papillomavirus (HPV) and cervical cancer. Genewa..

WHO, (2020). Sustainable Development Goals (SDGs). Genewa. 